\title{
Salmonella SEROVARS ISOLATED FROM HUMANS IN SÃO PAULO STATE, BRAZIL, 1996-2003
}

\author{
Sueli A. FERNANDES(1), Ana T. TAVECHIO(1), Ângela C.R. GHILARDI(1), Ângela M.G. DIAS(2), Ivete A.Z.C. de ALMEIDA(3) \& Leyva C.V. de MELO(1)
}

\section{SUMMARY}

Salmonellosis remains an important cause of diarrheal illness in humans in São Paulo State, Brazil. In this study were identified 3554 Salmonella isolates from human infections, during the period 1996-2003. Among 68 different serovars determined, S. Enteritidis was the most frequent one in gastrointestinal and extra-intestinal infections accounting for $67.4 \%$ of all isolates. $S$. Typhimurium and S. enterica subsp. enterica (4,5,12:i:-) were most frequently isolated from children aged < 1-4 year-old, in contrast, people with $S$. Enteritidis infections were most likely to be 20-50 year-old. In our geographic area the continued laboratorial surveillance of salmonellosis, including serotyping, has showed the trends in Salmonella serovars causing infections in humans throughout the time.

KEYWORDS: Salmonella; S. Enteritidis; Serovars.

\section{INTRODUCTION}

Salmonella spp. remains an important cause of diarrheal illness in humans in many parts of the world and also in São Paulo State, Brazil, despite the general improvement in sanitary conditions.

The Salmonella genus consists of only two species, S. enterica which is divided into six subspecies: $S$. enterica subsp. enterica, $S$. enterica subsp. salamae, S. enterica subsp. arizonae, S. enterica subsp. diarizonae, S. enterica subsp. houtenae, and S. enterica subsp. indica; and $S$. bongori. This nomenclature reflects the present Salmonella taxonomy ${ }^{5,18}$. Serovars belonging to $S$. enterica subsp. enterica are designated by a name usually related to the geographical place where those serovars were first isolated. This name is written in roman letters (not italicized) and the first letter is a capital letter. Serovars belonging to other subspecies are designated by their antigenic formulae, following the subspecies name.

The serotyping is based in a document called the Kauffmann-White Scheme ${ }^{25}$ and consists in the characterization, generally by slide agglutination tests, of the somatic $(\mathrm{O})$ and flagellar $(\mathrm{H})$ antigens. Updating this scheme was responsibility of the WHO Collaborating Centre for Reference and Research on Salmonella, which is revised each five years. In the last revision of this scheme were described 2501 serovars $^{25}$.

Serotyping is the epidemiological marker of choice for subdividing Salmonella spp. strains. Most of the information regarding the prevalence of salmonellae has been based on passive laboratory
Salmonella surveillance. Reporting of animal and human salmonellosis has been substantially underestimated. However, the surveillance data allow broad comparisons and identify trends, reservoirs and routes of transmission of Salmonella serovars.

During the first six decades of the 1900s, the main issues with respect to salmonellosis were the occurrence of typhoid fever in humans, which declined dramatically in the following years in many parts of the world, as well in São Paulo State ${ }^{23.32}$.

Since 1940, there has been a rapid increase in the isolation of non typhoidal serovars which are recognized as one of the major causes of food poisoning worldwide ${ }^{4}$. This was particularly the case of $S$. Typhimurium, which has been reported to be one of the most common causes of human salmonellosis ${ }^{10,17,23,32,37}$.

More recently, specific serovars have been linked with certain foods or exposures. In many countries, there has been an increased incidence of gastrointestinal infections caused by $S$. Enteritidis ${ }^{27,28,30}$ and the outbreaks identified have been repeatedly associated with raw or undercooked eggs 2,3,9,22 $^{2}$.

This present report analyzed particularly the trends in Salmonella serovars causing infections in humans in São Paulo State, during 1996 to 2003 .

\section{METHODS}

A total of 3554 Salmonella strains were isolated from human origin in different geographic locations from São Paulo State during the period 


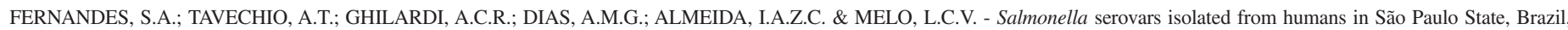
1996-2003. Rev. Inst. Med. trop. S. Paulo, 48(4): 179-184, 2006.

of 1996-2003, which were received and analyzed at the Laboratory of Enteric Pathogens, Adolfo Lutz Institute, São Paulo. These strains were confirmed to be Salmonella genus on the basis of reduced number of conventional biochemical tests ${ }^{11}$.

The serotyping of Salmonella strains were performed according to POPOFF $^{25}$ and POPOFF \& LE MINOR ${ }^{26}$, by slide agglutination tests and the Salmonella antisera used were prepared in our laboratory by using standard guidelines ${ }^{19}$. The somatic $(\mathrm{O})$ antigens were detected directly from growth bacterium on nutrient agar and the flagellar $(\mathrm{H})$ antigens were identified by selecting the most mobile bacteria from cultivation on Sven-Gard semi-solid medium ${ }^{14}$. After identifying one of the flagellar phases, each strain was grown again on other SvenGard semi-solid medium plate containing the antiserum related to the previously detected flagellar phase, in order to identify the other phase.

Some serovars also required the subspecies level determination, which was done based on a small number of biochemical characteristics $^{25}$.

\section{RESULTS}

A total of 68 different serovars were identified among the 3554 strains isolated from humans, and the annual distribution of the most frequent ones is shown in Table 1. During the entire 8-year period, the top five reported Salmonella serovars: $S$. Enteritidis, $S$. Typhimurium, S. enterica subsp. enterica $(4,5,12: \mathrm{i}:-), S$. Typhi and $S$. Dublin, accounted for $84.1 \%$ of all isolates.

In the studied period, $S$. Enteritidis was the most frequent serovar accounting for 2396 strains (67.4\%), followed by S. Typhimurium, $185(5.2 \%)$ (Table 1). The annual prevalence of $S$. Enteritidis remained high among the other 67 identified serovars.

A known clinical source was reported for 3509 (98.7\%) isolates, which in majority $2922(83.2 \%)$ were from stool samples, other 410 $(11.5 \%)$ were from blood, $58(1.6 \%)$ were from urine, $52(1.4 \%)$ were from cerebrospinal fluid, and $67(2.3 \%)$ were isolated from other sources (Table 2).

S. Enteritidis was the most frequently serovar identified in the different sites of Salmonella isolation (Table 2). Besides $S$. Enteritidis, 16 different serovars were identified among the strains isolated from blood being $S$. Typhi, $S$. Dublin, $S$. Typhimurium and $S$. enterica subsp. enterica (4,5,12:i:-) the prevalent ones.

The distribution of Salmonella serovars by age groups is shown in Table 3. Information on patient age was available for $80.7 \%$ of the reported isolates and most of them (52.6\%) were isolated from people aged 20-59 year-old and other $20.5 \%$, were from children aged $<1-4$ year-old.

S. Typhimurium and S. enterica subsp. enterica (4,5,12:i:-) were most frequently isolated from children $<1-4$ year-old, in contrast, people with $S$. Enteritidis infection were most likely to be $20-59$ yearold (Fig. 1).

\section{DISCUSSION}

In this study we described 3554 culture confirmed Salmonella infections for 8-year period, 1996-2003, however the number of

Table 1

Annual number of Salmonella isolates from humans: 15 most frequent serovars, 1996-2003

\begin{tabular}{|c|c|c|c|c|c|c|c|c|c|}
\hline \multirow[b]{2}{*}{ Serovar } & \multicolumn{8}{|c|}{ Year } & \multirow[b]{2}{*}{ TOTAL (\%) } \\
\hline & 1996 & 1997 & 1998 & 1999 & 2000 & 2001 & 2002 & 2003 & \\
\hline Enteritidis & 352 & 262 & 268 & 331 & 309 & 316 & 262 & 296 & $2396(67.4)$ \\
\hline Typhimurium & 17 & 3 & 35 & 24 & 22 & 19 & 37 & 28 & $185(5.2)$ \\
\hline 4,5,12:i:- & 55 & 5 & 31 & 25 & 7 & 19 & 26 & 16 & $184(5.1)$ \\
\hline Typhi & 31 & 12 & 20 & 27 & 12 & 17 & 14 & 7 & $140(4.0)$ \\
\hline Dublin & 7 & 8 & 19 & 5 & 9 & 11 & 13 & 14 & $86(2.5)$ \\
\hline Infantis & 17 & 5 & 11 & 1 & 2 & 15 & 26 & 2 & $79(2.3)$ \\
\hline Agona & 13 & 2 & 4 & 9 & 6 & 5 & 3 & 4 & $46(1.4)$ \\
\hline Panama & 3 & 1 & 1 & 7 & 4 & 3 & 6 & 9 & $34(1.0)$ \\
\hline Oranienburg & 4 & 4 & 5 & 3 & 2 & 2 & 7 & 4 & $31(0.8)$ \\
\hline Saintpaul & - & - & 1 & - & 1 & 6 & 17 & 5 & $30(0.8)$ \\
\hline Newport & 8 & - & 2 & 3 & 2 & 6 & 2 & 3 & $26(0.7)$ \\
\hline Hadar & 7 & 3 & 2 & - & 3 & - & 1 & 6 & $22(0.6)$ \\
\hline Javiana & 5 & 1 & 3 & 2 & 2 & 5 & - & 3 & $21(0.5)$ \\
\hline Mbandaka & 1 & - & 1 & 1 & - & 2 & 7 & 2 & $14(0.3)$ \\
\hline Shwarzengrund & 2 & - & 5 & 2 & - & 1 & 2 & 1 & $13(0.4)$ \\
\hline Other (53 Serovars) & 37 & 21 & 33 & 26 & 29 & 31 & 29 & 41 & $247(7.0)$ \\
\hline Total & 559 & 327 & 441 & 466 & 410 & 458 & 452 & 441 & $3554(100.0)$ \\
\hline
\end{tabular}

Note: Data are No. of isolates with the serovars. 


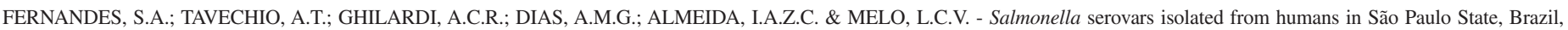
1996-2003. Rev. Inst. Med. trop. S. Paulo, 48(4): 179-184, 2006.

Table 2

Number of Salmonella isolates from humans, by source of isolation and serovar: 15 most frequent serovars, São Paulo, Brazil, 1996-2003

\begin{tabular}{|c|c|c|c|c|c|c|c|}
\hline \multirow[b]{2}{*}{ Serovar } & \multicolumn{6}{|c|}{ Source } & \multirow[b]{2}{*}{ TOTAL } \\
\hline & Stool & Blood & $\mathrm{CSF}^{*}$ & Urine & Other** & Unknown & \\
\hline Enteritidis & 2136 (91.2) & $148(6.3)$ & $29(1.2)$ & $21(0.9)$ & $35(14)$ & 27 & 2396 \\
\hline Typhimurium & $147(79.4)$ & $31(16.8)$ & $5(2.8)$ & $2(1.0)$ & - & - & 185 \\
\hline 4,5,12:i:- & $119(65.7)$ & $48(26.5)$ & $3(1.7)$ & 3 (1.7) & $8(4.4)$ & 3 & 184 \\
\hline Typhi & $45(32.3)$ & $91(65.5)$ & - & $3(2.1)$ & $3(2.1)$ & 1 & 140 \\
\hline Dublin & $13(15.2)$ & $56(65.2)$ & $1(1.1)$ & $9(10.4)$ & $7(8.1)$ & - & 86 \\
\hline Infantis & 75 (94.9) & - & $1(1.3)$ & $3(3.8)$ & - & - & 79 \\
\hline Agona & $41(91.2)$ & $3(6.6)$ & $1(2.2)$ & - & - & 1 & 46 \\
\hline Panama & $26(81.4)$ & $1(3.1)$ & $2(6.2)$ & $2(6.2)$ & $1(3.2)$ & 2 & 34 \\
\hline Oranienburg & 25 (80.6) & $3(9.7)$ & - & - & $3(9.7)$ & - & 31 \\
\hline Saintpaul & $28(93.4)$ & $2(6.6)$ & - & - & - & - & 30 \\
\hline Newport & 22 (91.6) & $1(4.2)$ & - & $1(4.2)$ & - & 2 & 26 \\
\hline Hadar & $20(91.0)$ & $1(4.5)$ & $1(4.5)$ & - & - & - & 22 \\
\hline Javiana & 19 (90.6) & $1(4.7)$ & $1(4.7)$ & - & - & - & 21 \\
\hline Mbandaka & $13(92.8)$ & $1(7.2)$ & - & - & - & - & 14 \\
\hline Shwarzengrund & $10(76.9)$ & $2(15.4)$ & - & - & $1(7.7)$ & - & 13 \\
\hline Other (53 Serovars) & $183(81.1)$ & 24 (104) & $8(3.5)$ & $14(6.1)$ & $9(3.9)$ & 9 & 247 \\
\hline Total & $2922(83.3)$ & $413(11.8)$ & $52(1.5)$ & $58(1.6)$ & $64(1.8)$ & 45 & 3554 \\
\hline
\end{tabular}

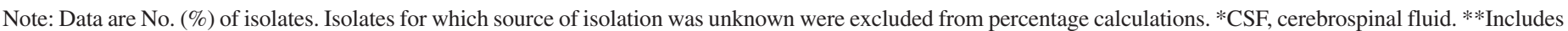
wound, sputum, abscess and unspecified other category.

Table 3

Distribution, by age group and serovar, of the 15 most frequently reported serovars of Salmonella isolates from humans, São Paulo State, Brazil, 1996-2003

\begin{tabular}{|c|c|c|c|c|c|c|c|c|}
\hline \multirow[b]{2}{*}{ Serotype } & \multicolumn{7}{|c|}{ Age, years } & \multirow[b]{2}{*}{ TOTAL } \\
\hline & $<1$ & $1-4$ & $5-14$ & $15-19$ & $20-59$ & $\geq 60$ & Unknown & \\
\hline Enteritidis & $110(5.8)$ & $118(6.3)$ & $293(15.5)$ & $200(10.7)$ & 1079 (57.3) & $82(4.4)$ & 514 & 2396 \\
\hline Typhimurium & 37 (22.6) & $51(31.2)$ & $10(6.2)$ & $4(2.5)$ & $52(31.9)$ & $9(5.6)$ & 22 & 185 \\
\hline 4,5,12:i:- & $36(22.9)$ & $53(33.7)$ & $12(7.7)$ & $2(1.3)$ & $49(31.3)$ & $5(3.1)$ & 27 & 184 \\
\hline Typhi & $1(0.8)$ & $5(4.2)$ & $17(14.4)$ & $12(10.2)$ & $78(66.1)$ & $5(4.3)$ & 22 & 140 \\
\hline Dublin & - & $7(8.5)$ & $2(2.5)$ & $5(6.0)$ & $57(69.5)$ & $11(13.4)$ & 4 & 86 \\
\hline Infantis & 10 (13.9) & $4(5.6)$ & $6(8.4)$ & $5(6.9)$ & $42(58.3)$ & $5(6.9)$ & 7 & 79 \\
\hline Agona & 18 (39.1) & $8(17.5)$ & $5(10.8)$ & $1(2.2)$ & $14(30.4)$ & - & - & 46 \\
\hline Panama & $2(6.4)$ & $8(25.8)$ & $2(65)$ & $1(3.2)$ & $18(39.1)$ & - & 3 & 34 \\
\hline Oranienburg & $2(6.5)$ & $1(3.3)$ & $5(16.1)$ & $2(6.4)$ & $21(67.7)$ & - & - & 31 \\
\hline Saintpaul & 3 (11.2) & $14(51.8)$ & - & $1(3.7)$ & $9(33.3)$ & - & 3 & 30 \\
\hline Newport & $1(3.9)$ & $6(23.1)$ & $1(3.9)$ & - & $17(65.2)$ & $1(3.9)$ & - & 26 \\
\hline Hadar & - & $5(22.8)$ & - & $1(4.5)$ & $16(72.7)$ & - & - & 22 \\
\hline Javiana & $4(19.0)$ & $3(14.2)$ & $2(9.5)$ & $1(4.7)$ & $9(42.8)$ & $2(9.5)$ & - & 21 \\
\hline Mbandaka & - & $1(7.1)$ & $7(50.1)$ & - & $3(21.4)$ & $3(21.4)$ & - & 14 \\
\hline Shwarzengrund & $4(30.7)$ & $3(23.0)$ & - & $1(7.8)$ & $5(38.5)$ & - & - & 13 \\
\hline $\begin{array}{l}\text { Other } \\
\text { (53 Serovars) }\end{array}$ & $39(23.7)$ & $33(20.1)$ & $14(8.5)$ & $16(9.7)$ & $41(25.1)$ & $18(10.9)$ & 83 & 247 \\
\hline Total & $270(9.5)$ & $320(11.1)$ & $376(13.1)$ & $252(8.8)$ & $1510(52.6)$ & $141(4.9)$ & 685 & 3554 \\
\hline
\end{tabular}

Note: Data are No. $(\%)$ of isolates. Persons for whom age was unknown were excluded from percentage calculations. 


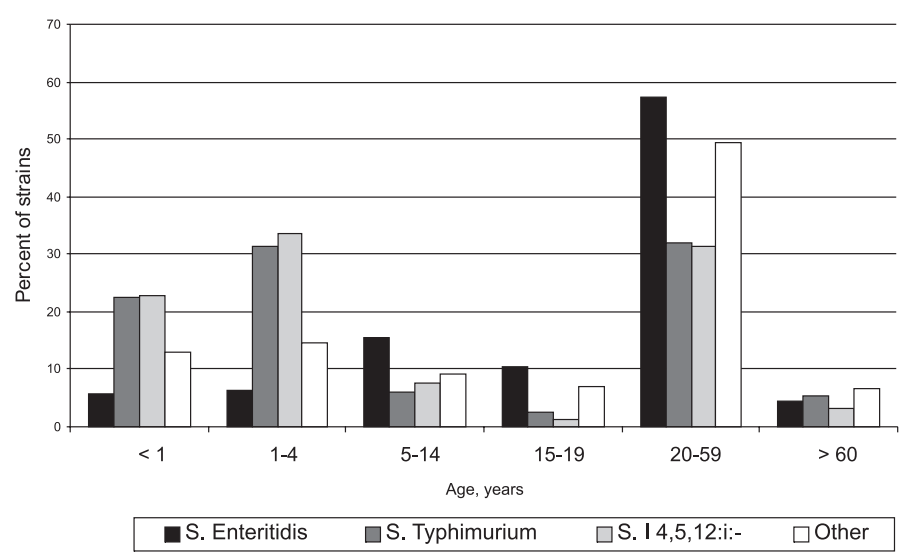

Fig. 1 - Percentage of distribution by age of patients for Salmonella serovars in São Paulo State, 1993-2003.

infection that goes unreported has been estimated to be much greater than the number of reported infections.

Characterization of Salmonella serovars in São Paulo State began in 1950 and has been conducted by Laboratory of Enteric Pathogens in Adolfo Lutz Institute. These laboratorial surveillance data are periodically summarized and published ${ }^{32,33,34}$. By this way, it has been detected the changing patterns of Salmonella serovars caused by the trend increase of $S$. Enteritidis isolated from human and non human sources, since $1993^{33}$.

There have been significant changes in the epidemiology of salmonellosis in São Paulo, Brazil, over the past 54 years, by comparing these results with the previous reports.

$S$. Typhi showed a striking declining trend after late 70 ' $\mathrm{s}^{32}$, although typhoid fever is still a public health concern, due to poor sanitary conditions and unsatisfactory personal hygiene of people having a low standard of living. This serovar represented the fourth most prevalent among the identified isolates (Table 1) and the second one among strains isolated from blood (Table 2).

In São Paulo State, a substantial rise in $S$. Typhimurium changed the patterns in the 70's accounting for $77.7 \%$ of all serovars of clinical sources, and presented an epidemic feature ${ }^{32}$. The following years (1977-90) were characterized by a declining trend of $S$. Typhimurium, a significant rise of the isolation of other serovars including $S$. Agona ${ }^{32}$. During the period 1991-95, it was reported the changing patterns of Salmonella serovars in São Paulo State caused by the world trend increase of $S$. Enteritidis ${ }^{33}$.

During the last decades $S$. Enteritidis and $S$. Typhimurium have emerged as the predominant serovars in the majority of countries disposing this information ${ }^{27,29,36}$. Our findings indicate the general steady high prevalence in $S$. Enteritidis infections during the reporting period (Table 1), that is consistent with previous studies in São Paulo State, Brazil $^{33}$.

In São Paulo State, the remarkable increase in the incidence of human $S$. Enteritidis isolates began to be noticed in $1993(10.1 \%)$ and since 1994, accounted for $43.3 \%$ of all isolates. It became the most frequent serovar responsible for foodborne outbreaks and sporadic cases of human gastrointestinal diseases ${ }^{33}$. Many of the outbreaks reported have been epidemiologically linked to the consumption of raw or undercooked eggs, to a lesser extent, chicken as vehicles for transmission ${ }^{2,3,4,16,24}$. The frequent occurrence of this serovar in chickens suggests that poultry may be an important reservoir, a finding that is consistent with almost all other studies in other countries. The increase of $S$. Enteritidis in our State, is clearly related to the progression of phage type 4 (PT-4) strains, as previously detected ${ }^{12,15}$, which has also emerged as the predominant phage type in Europe ${ }^{36}$. Thus, São Paulo State has also been part of the global pandemic of S. Enteritidis observed in the late $1980 \mathrm{~s}^{28}$.

Besides the prevalence of $S$. Enteritidis, other serovars like $S$. Typhimurium, $S$. Agona, $S$. Typhi, and $S$. enterica subsp. enterica (4,5,12:i:-) were among the most frequent ones (Table 1). S. enterica subsp. enterica (4,5,12:i:-), the atypical and monophasic serovar, firstly identified in 70's in São Paulo ${ }^{7}$, has been among the most prevalent serovars during the last decade, including in other countries ${ }^{10}$. It shares almost all antigenic factors with $S$. Typhimurium and some studies on phenotypic and molecular characterization of these two serovars have been carried out, including in our laboratory ${ }^{35}$, in order to confirm their relationship.

There has not been detected any significant change in the prevalence of the main serovars isolated from humans, by comparing with those ones reported in the last period, 1991-1995 ${ }^{33}$. The isolation rates of the most common Salmonella serovars from human infections, especially $S$. Enteritidis, generally showed the same trends in magnitude as those Salmonella serovars isolated from non human sources and identified during 1996 to $2000^{34}$.

However as it happens almost every year, the list of different Salmonella serovars detected in an specific region, increases by the addition of some serovars that had not been previously detected. In this way, $S$. Businga, $S$. enterica subsp. houtenae $40: \mathrm{z}_{4}, \mathrm{z}_{24}:-, S$. Weltevreden, $S$. IIIb 50:r:z (indole-positive), $S$. IIIb 61:c:-, $S$. Corvallis, and $S$. Cotia were detected for the first time in human infections in São Paulo State, during the studied period. Among these serovars, $S$. Corvallis was firstly isolated in 1993 from human stool and it was observed that its prevalence has been increasing in cases of human infection and in poultry isolates (recent data from our Enteric Pathogens Laboratory).

As regards the samples from human origin, the great majority of strains $(60.1 \%)$ were isolated from gastrointestinal infections, which are related to the significant number of foodborne outbreaks occurred during that period ${ }^{1,16,24}$. Among the stool isolates were identified 52 different serovars with the total predominance of $S$. Enteritidis. However, it was detected a very significant percentage of Salmonella strains, $587(12.0 \%)$, associated with extra-intestinal infections. Several serovars with somatic antigens belonging to B, C1, and D1 groups, more commonly cause invasive infection and are frequently isolated from blood. Although Salmonella virulence factors are not well understood, differences in the somatic antigen-side chain of the lipopolysaccharide seem to be important ${ }^{37}$. 
Serotyping of Salmonella strains detected 18 different serovars from blood isolates, 12 from cerebrospinal isolates, 10 from fluids and nine from urine isolates (data not shown). However, $S$. Enteritidis was the most common serovar isolated from extra-intestinal sources, followed by $S$. Typhi, $S$. Dublin, $S$. enterica subsp. enterica $(4,5,12: \mathrm{i}:-)$, and $S$. Typhimurium (Table 2), findings which were similar to other studies in different countries ${ }^{8,20,23}$.

Extra-intestinal salmonellosis is commonly observed in children, immunocompromised patients, and elderly people. In adult patients with acquired immunodeficiency syndrome (AIDS) several infections were described, predominantly caused by $S$. Enteritidis and $S$. Dublin ${ }^{8,13,20,21}$. In this study the prevalence of $S$. Enteritidis (52.0\%) and $S$. Dublin (36.0\%) among patients with AIDS was also observed.

Salmonella isolation rates were considered high for infants up to 4 year-old (Table 3), mainly from extra-intestinal sites and the reasons for this are unknown but may include host susceptibility, exposure differences and sample from ill infants were cultured. An important difference in the prevalence of Salmonella serovar in different age groups was observed, as $S$. Typhimurium and $S$. enterica subsp. enterica (4,5,12:i:-) for infants up to 4 year-old (Fig.1). Similar results have been reported by other countries, although with higher incidence rates for infants, specially $<1$ year-old ${ }^{23,29}$.

$S$. Typhi was consistently the most common extra-intestinal serovar isolated from adults. However among 118 culture-positive typhoid fever cases with known age, six $(5.0 \%)$ were in children aged under five year-old and 29 (24.5\%) 5-19 year-old (Table 3). The incidence of typhoid fever in these groups was considered significant, as well as observed by other reports ${ }^{6,31}$.

The high prevalence of $S$. Enteritidis infection among adults (2059 year-old) which are more exposed to the consumption of all kinds of food, it is more likely associated to greater general outbreaks of gastroenteritis including familiar outbreaks.

These data have several limitations considering that only people who were ill, sought care, had a stool culture, and had the Salmonella isolate forwarded to be serotyped could be included for the reported data. For these reasons, it is recognized that the burden of illness caused by salmonellosis is greatly undereported in São Paulo State.

Serotyping remains as an important laboratory tool that helps public health researchers to better understand and define the epidemiology of salmonellosis in a geographic area. Measuring trends in serovars over time can provide information about emerging serotypes and about the efficacy of prevention and control measures.

\section{RESUMO}

\section{Sorovares de Salmonella isolados de humanos no Estado de São Paulo, Brasil, 1996-2003}

A salmonelose permanece uma importante causa de doença diarréica em humanos no Estado de São Paulo, Brasil. Nesse estudo foram identificados 3554 isolados de Salmonella de infecções humanas, durante o período 1996-2003. Entre os 68 diferentes sorovares determinados, $S$. Enteritidis foi predominante em infecções gastrointestinais e extra-intestinais, responsável por $67.4 \%$ de todos os isolados. S. Typhimurium e S. enterica subsp. enterica $(4,5,12: \mathrm{i}:-)$ foram mais freqüientemente isolados de crianças com idade de $<1$ a 4 anos, em contraste, infecções por $S$. Enteritidis foram predominantes em pessoas entre 20 e 50 anos. A contínua vigilância laboratorial das salmoneloses, incluindo a sorotipagem, tem evidenciado os sorovares de Salmonella causando infecções humanas em nossa área geográfica ao longo do tempo.

\section{REFERENCES}

1. ALMEIDA, I.A.Z.C.; PERESI, J.T.M.; CARVALHO, I.S. et al. - Salmonella: sorotipos identificados na região de São José do Rio Preto/SP, no período de 1990 -1999. Rev. Inst. Adolfo Lutz, 59: 33-37, 2000.

2. ALTEKRUSE, S.F.; COHEN, M.L. \& SWERDLOW, D.L. - Emerging foodborne diseases. Emerg. infect. Dis., 3: 285-293, 1997.

3. ARAÚJO, E.; PACHECO, M.A.S.R.; BONI, R.F. et al. - Surtos alimentares por Salmonella enteritidis associados ao consumo de alimentos à base de ovos, em Sorocaba, SP. Hig. Alim., 9: 24-26, 1995.

4. BANGTRAKULNONTH, A.; PORNREONGWONG, S.; PULSRIKARN, C. et al. Salmonella serovars from humans and other sources in Thailand, 1993-2002. Emerg. infect. Dis., 10: 131-136, 2004.

5. BRENNER, F.W.; VILLAR, R.G.; ANGULO, F.J., TAUXE, R. \& SWAMINATHAN, B. - Salmonella nomenclature. J. clin. Microbiol., 38: 2465-2467, 2000.

6. BROOKS, W.A.; HOSSAIN, A.; GOSWAMI, D. et al. - Bacteremic typhoid fever in children in an urban slum, Bangladesh. Emerg. infect. Dis.; 11: 326-329, 2005.

7. CALZADA, C.T.; NEME, S.N.; IRINO, K. et al. - Sorotipos de Salmonella identificados no período 1977-1982, no Instituto Adolfo Lutz, São Paulo, Brasil. Rev. Inst. Adolfo Lutz, 44: 1-18, 1984.

8. CELUM, C.L.; CHAISSON, R.E.; RUTHERFORD, G.W.; BARNHART, J.L \& ECHENBERG, D.F. - Incidence of salmonellosis in patients with AIDS. J. infect. Dis., 156: 998-1002, 1987.

9. CENTERS FOR DISEASE CONTROL AND PREVENTION - Outbreaks of Salmonella serotypes Enteritidis infection associated with eating shell eggs - United States, 19992001. M.M.W.R., 51: 1150-1152, 2003.

10. ECHEITA, M.A.; ALADUENA, A.N.; DÍEZ, R. et al. - Distribución de los serotipos y fagotipos de Salmonella de origen humano aislados en España en 1997-2001. Enferm. infecc. Microbiol. clin., 23: 127-134, 2005.

11. EWING, W.H. - Edwards and Ewing's identification of Enterobacteriaceae. 4. ed. New York, Elsevier Science, 1986.

12. FERNANDES, S.A.; GHILARDI, A.C.R.; TAVECHIO, A.T. ; MACHADO, A.M.O. \& PIGNATARI, A.C.C. - Phenotypic and molecular characterization of Salmonella Enteritidis strains isolated in São Paulo, Brazil. Rev. Inst. Med. trop. S. Paulo., 45: 59-63, 2003

13. FERNÁNDEZ GUERRERO, M.L.; RAMOS, J.M.; NÚÑEZ, A.; CUENCA, M. \& GÓRGOLAS, M. - Focal infections due to non-typhi Salmonella in patients with AIDS: report of 10 cases and review. Clin. infect. Dis., 25: 690-697, 1997.

14. INSTITUT PASTEUR PRODUCTION - Mielieux et réactifs de Laboratoire Pasteur. Paris, Institut Pasteur, 1978. p. 168-170.

15. IRINO, K.; FERNANDES, S.A.; TAVECHIO, A.T.; NEVES, B.C. \& DIAS, A.M.G. Progression of Salmonella Enteritidis phage type 4 strains in São Paulo State, Brazil. Rev. Inst. Med. trop. S. Paulo., 38: 193-196, 1996. 


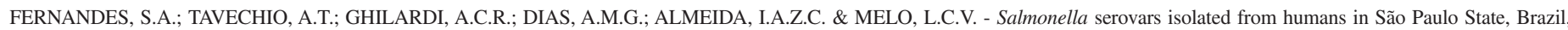
1996-2003. Rev. Inst. Med. trop. S. Paulo, 48(4): 179-184, 2006.

16. KAKU, M.; PERESI, J.T.M.; TAVECHIO, A.T. et al. - Surto alimentar por Salmonella Enteritidis no Noroeste do Estado de São Paulo, Brasil. Rev. Saúde públ. (S. Paulo), 29: 127-131, 1995.

17. KHAKHRIA, R.; WOODWARD, D.; JOHNSON, W.M. \& POPPE, C. - Salmonella isolated from humans, animals and other sources in Canada, 1983-92. Epidem. Infect., 119: 15-33, 1997.

18. LE MINOR, L. \& POPOFF, M.Y. - Request for an opinion. Designation of Salmonella enterica sp. nov., nom. rev., as the type and only species of the genus Salmonella. Int. J. syst. Bact., 37: 465-468, 1987.

19. LE MINOR, L. \& RHODE, R. - Guidelines for the preparation of Salmonella antisera. WHO collaborating centre for reference and research on Salmonella. Paris, Pasteur Institute, 1989.

20. LEVINE, W.C.; BUEHLER, J.W.; BEAN, N.H. \& TAUXE, R.V. - Epidemiology of nontyphoidal Salmonella bacteremia during the human immunodeficiency virus epidemic. J. infect. Dis., 164: 81-87, 1991.

21. LOURENÇO, M.C.S.; REIS, E.F.M.; VALLS, R.; ASENSI, M.D. \& HOFER, E. Salmonella enterica subsp. houtenae serogroup O:16 in a HIV positive patient: case report. Rev. Inst. Med. trop. S. Paulo., 46: 169-170, 2004

22. MISHU, B.; KOEHLER, J.; LEE, L.A. et al. - Outbreaks of Salmonella enteritidis infections in the United States, 1985-1991. J. infect. Dis., 169: 547-552, 1994.

23. OLSEN, S.J.; BISHOP, R.; BRENNER, F.W. et al. - The changing epidemiology of Salmonella: trends in serotypes isolated from humans in the United States, 19871997. J. infect. Dis., 183: 753-761, 2001.

24. PERESI, J.T.M.; ALMEIDA, I.A.Z.C.; LIMA, S.I. et al. - Surtos de enfermidades transmitidas por alimentos causados por Salmonella Enteritidis. Rev. Saúde públ. (S. Paulo), 32: 477-483, 1998.

25. POPOFF, M.Y. - Antigenic formulas of the Salmonella serovars. WHO collaborating centre for reference and research on Salmonella. 8. ed. Paris, Pasteur Institute, 2001 .

26. POPOFF, M.Y. \& LE MINOR, L.E. - The genus Salmonella. In: BRENNER, D.J.; KRIEG, N.R.; STALEY, J.T., ed. Bergey's manual of systematic Bacteriology. 2. ed. New York, Springer, 2005. v. 2, p. 764-799.

27. POPPE, C. - Epidemiology of Salmonella enterica serovar Enteritidis. In: SAEED, A.M.; GAST, R.K.; POTTER, M.E. \& WALL, P.G., ed. Salmonella enterica serovar Enteritidis in humans and animals: epidemiology, pathogenesis, and control. Ames, Iowa State University Press, 1999. p. 3-18.
28. RODRIGUE, D.C.; TAUXE, R.V. \& ROWE, B. - International increase in Salmonella enteritidis: a new pandemic? Epidem. Infect., 105: 21-27, 1990.

29. SCUDERI, G. - Epidemiology of Salmonella enterica serovar Enteritidis infections in Italy. In: SAEED, A.M.; GAST, R.K.; POTTER, M.E. \& WALL, P.G., ed. Salmonella enterica serovar Enteritidis in humans and animals: epidemiology, pathogenesis, and control. Ames, Iowa State University Press, 1999. p. 111-115.

30. SHIMONI, Z.; PITLIK, S.; LEIBOVICI, L. et al. - Nontyphoid Salmonella bacteremia age-related differences in clinical presentation, bacteriology, and outcome. Clin. infect. Dis., 28: 822-827, 1999.

31. SINHA, A.; SAZAWAL, S.; KUMAR, R. et al. - Typhoid fever in children aged less than 5 years. Lancet, 354 (9180): 734-737, 1999.

32. TAUNAY, A.E.; FERNANDES, S.A.; TAVECHIO, A.T. et al. - The role of public health laboratory in the problem of salmonellosis in São Paulo, Brazil. Rev. Inst. Med. trop. S. Paulo, 38: 119-127, 1996.

33. TAVECHIO, A.T.; FERNANDES, S.A.; NEVES, B.C.; DIAS, A.M.G. \& IRINO, K. Changing patterns of Salmonella serovars: increase of Salmonella Enteritidis in São Paulo, Brazil. Rev. Inst. Med. trop. S. Paulo, 38: 315-322, 1996.

34. TAVECHIO, A.T.; GHILARDI, A.C.R.; PERESI, J.T.M. et al. - Salmonella serotypes isolated from nonhuman sources in São Paulo, Brazil, from 1996 through 2000. J. Food protect., 65: 1041-1044, 2002.

35. TAVECHIO, A.T.; GHILARDI, A.C.R. \& FERNANDES, S.A. - "Multiplex PCR" identification of the atypical and monophasic Salmonella enterica subsp. enterica serotype 1,4[5],12:i:- in São Paulo State, Brazil: frequency and antibiotic resistance patterns. Rev. Inst. Med. trop. S. Paulo, 46: 115-117, 2004.

36. WALL, P.G. \& WARD, L.R. - Epidemiology of Salmonella enterica serovar Enteritidis phage type 4 in England and Wales. In: SAEED, A.M.; GAST, R.K.; POTTER, M.E. \& WALL, P.G., ed. Salmonella enterica serovar Enteritidis in humans and animals: epidemiology, pathogenesis, and control. Ames, Iowa State University Press, 1999. p. $19-25$.

37. WONG, S.S.Y.; YUEN, K.Y.; YAM, W.C.; LEE, T.Y. \& CHAU, P.Y. - Changing epidemiology of human salmonellosis in Hong Kong, 1982-93. Epidem. Infect., 113: 425-434, 1994.

Received: 14 December 2005

Accepted: 23 March 2006 